\title{
ГАЗЕТНІ СЛОВЕСНІ ШТАМПИ ПЕРІОДУ РЕВОЛЮЦІЇ ГІДНОСТІ В МОВІ УКРАЇНСЬКОЇ ПЕРІОДИКИ
}

\author{
ОЛЕНА ЄФИМЕНКО \\ ДВНЗ „Переяслав-Хмельницький ДПУ імені Григорія Сковороди”, \\ Переяслав-Хмельницький - Україна \\ lenabalenko@ukr.net; ORCID: 0000-0002-0487-6224
}

\section{SZTAMPA GAZETOWA OKRESU REWOLUCJI GODNOŚCI W JĘZYKU PERIODYKÓW UKRAIŃSKICH}

\author{
OLENA JEFYMENKO \\ PUW „, Perejasław-Chmielnicki PUP im. Hryhorija Skovorody”, \\ Perejasław-Chmielnicki — Ukraina
}

\begin{abstract}
STRESZCZENIE. Środki masowego przekazu są najważniejszym źródłem szybkiego dostarczania do czytelników informacji o wydarzeniach i faktach życia społecznego oraz politycznego. Na podstawie analizy ukraińskich czasopism w latach 2013-2018 w artykule zostały prześledzone obciążenia semantyczne i pragmatyczne najpopularniejszej sztampy gazetowej okresu Rewolucji Godności. Udowodniono, że sztampa gazetowa tworzy system zabarwień emocjonalnych i ekspresyjnych, reprezentuje pragmatyczne informacje, jest atrakcyjna i precedensowa, nadaje publikacjom oryginalnego i atrakcyjnego brzmienia, wywołując u czytelnika odpowiednie uczucia i myśli, które pozwalają przygotować go do postrzegania pewnych wydarzeń politycznych, kształtując odpowiednią opinię publiczną o pewnym zabarwieniu aksjologicznym. Wydarzenia końca 2013 r. i początku 2014 r. zostały szeroko przedstawione w sztampach współczesnego języka ukraińskiego.
\end{abstract}

Słowa kluczowe: sztampa gazetowa, związki wyrazowe okresu Rewolucji Godności, język mediów, obciążenie semantyczne i pragmatyczne, atrakcyjność, precedensowość 


\title{
NEWSPAPER CLICHES USED DURING REVOLUTION OF DIGNITYIN LANGUAGE OF UKRAINIAN PERIODICALS
}

\author{
OLENA YEFYMENKO \\ DVNZ „Pereyaslav-Khmelnytskyi DPY after Grygorii Skovoroda”, \\ Pereyaslav-Khmelnytskyi — Ukraine
}

\begin{abstract}
Mass media are the most important source of prompt informing the readers about events and facts of social and political life. On the basis of the analysis of the Ukrainian periodicals of 2013-2018, this scientific research aims to examine the semantic and pragmatic load of some common newspaper cliches used during Revolution of Dignity. It is proved that newspaper cliches express the system of shades of emotional and expressive coloring, represent pragmatic information. They are engaging, precedent-setting and that makes publications more original and appealing, causing the reader to feel certain feelings and have some thoughts, setting the perception of some political events, forming corresponding public opinion of some axiological direction. Obviously, the events of the late 2013-early 2014 have been widely embodied in cliches of modern Ukrainian language.
\end{abstract}

Keywords: newspaper cliches, word-combinations used during Revolution of Dignity, language of mass media, semantic and pragmatic load, appeal, precedence

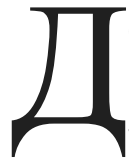

ослідження присвячене вивченню поширених газетних словесних штампів, словосполучень періоду Революції Гідності. Зміни в політичному суспільстві, як відомо, відбуваються не на полі битви, а в людській свідомості, що актуалізується в усі періоди соціальних потрясінь. XXI ст. багате на такі події. Але найтрагічніші в Україні припадають на к. 2013 - поч. 2014 р., зокрема: Революція Гідності, російська окупація Криму, війна на Сході України.

Мета цієї розвідки - простежити семантичне й прагматичне навантаження деяких поширених газетних штампів періоду Революції Гідності.

Лінгвістичні дослідження лексики, фразеології, зокрема й газетних штампів періоду Революції Гідності лише починають формуватися, до того ж лише в межах журналістських розвідок та поодиноких академічних робіт. Вивчення цього процесу стало предметом лінгвістичного аналізу М. Степаненка, О. Стишова, Н. Поліщук, С. Пролеєва, які аспектуально характеризують мову Революції Гідності, зокрема М. Степаненко з' ясовує нове лексичне значення іменника Майдан, аналізує й систематизує неологізми цього періоду, зокрема перифрази, вибудовуючи перифрастичні ряди, що номінують суспільно-політичні трансформації в Україні періоду 2004-2014 рр. [Степаненко 2015: 3]. У науковій розвідці Н. Поліщук описано нові термінологічні назви, що виникли в цей 
період, поширилися в мові публіцистики й номінують воєнні події в Криму, на Сході України та під час Революції Гідності; репрезентовано актуальні тематичні групи й описано семантичні процеси, які відбуваються в структурі лексичних значень цих термінологічних слів чи словосполучень [Поліщук 2014]. О. Стишов звертає увагу на тенденції поповнення нових термінів, що властиві мас-медіа, при цьому він зазначає, що, початок XXI століття характеризується переходом від індустріального до інформаційного суспільства, усеохопною глобалізацією переважної більшості сфер життя людей, новітніми значними досягненнями науково-технічного прогресу, військовими й етнічними конфліктами, пожвавленням міграції населення, соціально-політичними й економічними переворотами тощо. Низка цих та інших екстралінгвальних чинників чітко відбивається в мовах народів світу. У названому плані українська мова не становить винятку. Хоча варто зазначити, що темпи змін позамовних обставин за своєю стрімкістю та інтенсивністю випереджають темпи еволюції української мови загалом. Стан останньої, іï динаміка, трансформації, які в ній відбуваються, потребують грунтовного студіювання та пояснення" [Стишов 2016: 102]. С. Пролеєв розглядає причини появи нових лексем у XXI ст. у філософському аспекті й зауважує, що „Майдан потребує суттєвих новацій словника політичного і соціально-філософського дискурсів” [Пролеєв 2016: 6].

Проаналізувавши праці зазначених науковців, доходимо висновку, що в них здійснено спроби з'ясувати причини появи нових лексем та словосполучень у сучасному публіцистичному дискурсі, прагнення кваліфікувати їх семантично й прагматично, окреслити екстра- та інтралінгвальні чинники, що впливають на відповідні семантичні й прагматичні мовні зміни. Але окреслена проблематика потребує подальшого вивчення, оскільки сучасна суспільно-політична ситуація в Україні настільки складна й так бурхливо розвивається, що не все ще лінгвістично осмислено, зокрема потребують опису ключові словесні символи епохи, що входять до складу газетних штампів. Поповнення сучасної української мови новими усталеними словосполученнями, словесними штампами активізувалося в останні роки XXI ст. Цьому, як зауважувалося, сприяли зміни орієнтирів в ідеології й суспільно-політичних переконань українського народу. Спостерігаємо певні зрушення в семантиці словесних штампів, спроби моделювання відповідних прагматичних смислів. Л. Славова стверджує, що „мовленнєва діяльність, орієнтована на пропаганду тих або інших ідей, емоційний вплив на громадян країни та спонукання їх до політичних дій, для вироблення суспільної згоди, прийняття та обгрунтування соціально-політичних рішень в умовах множинності точок зору в суспільстві [...]. Вона здатна емоційно впливати на адресата, трансформуючи наявну у свідомості людини політичну картину світу" [Славова 2015: 6]. Напр., обіцянки Віктора Януковича (Тим самим конститучійні судді не лише створили небачений в модерній Свропі прецеедент, але й наплювали на обіцянки 
Віктора Януковича, котрий перед тим, як стати президентом, не раз полум 'яно обіияв всіляко відстоювати Конституцію-2004 іпередбаченунею парламентсько-президентську республіку /„Український тиждень”, 10.04 .2014 р./); нова-стара Конституція (На жаль, повернувши нову-стару Конституцію, автори иієё операції заклали колізію: за текстом Основного Закону від 1996 року, чергові вибори парламенту мали відбутися в березні четвертого року його повноважень, а вибори президента - в жовтні п'ятого року повноважень глави держави /„Український тиждень”, 10.04.2014р./). У першому прикладі простежуємо іронію, а другий - репрезентує явище внутрішньої антонімії, створюючи специфічний прагматичний ефект наявності суперечності в одному явищі.

Виразно простежуємо явище переходу словникового запасу з пасивного до активного, що проілюструємо на таких словесних штампах, напр., народне віче (Народне Віче в Кисві 1 грудня зібрало, за різними оиінками, від 500 тисяч до 1 мільйона людей /,УНІАН”, 21.11.2017р./); дух козацтва (На Майдані як і 500 років до того теж існувала своя територія волі, самоорганізація, феномен прямої демократії, тобто був присутній справжній дух козащтва /,FAKE OFF”, 6.04.2017р./); козацьке самоврядування (На кожному з них були присутні елементи козацького самоврядування та організації, проте найбільш яскраво иі елементи можна простежити на третьому етапі, після трагічних подій 19-22 січня 2014 р., коли Революція Гідності зазнала перших втрат (убивство С. Нігояна та М. Жизневського) /,FAKE OFF”, 6.04.2017 p./). Наведені приклади ілюструють відновлення актуальних для сучасних українців давніх понять у їхній мовній свідомості.

Аналіз періодики засвідчує активне вживання словесних штампів з лексемами євроінтеграція, Свромайдан, Майдан у прямому значенні, порівн.: $\boldsymbol{\epsilon в - ~}$ роінтеграція України (Тобто свроінтеграція Украӥни багато років була метою номер один [Таран 2013: 25]); студентський Євромайдан (Відправною точкою студентського Свромайдану в Украйні можна вважати 25 листопада [Таран 2013: 43]); два Майдани (Почався запуск брудного піару, щзоб два Майдани - на Європейській площі (опозииійний) і біля Стели незалежності (студентський) - зімтовхнути лобами, протиставити [Таран 2013: 45]). Актуалізовано й оригінальні метафоричні утворення, напр.: “в'язні Банкової” (“В'язні Банкової", після бійні на Банковій 1 грудня затримали дев'ятеро людей /заголовок, „Репортер”, 12.12.2013р./); “закони 16 січня”, “диктаторські закони", закони імені Колесніченка-Олійника (“Закони 16 січня", “диктаторські закони” і ряд інших епітетів - закони імені Колесніченка-Олійника отримали в суспільстві багато назв /„112UA”, 16.01.2015р./); “300 майданівців” ("300 майданівців" - назвав хтось людей, яких розігнали спеибійці під ранок 30 листопада. По аналогії зі спартаниями”/,Gazeta. ua”, 12.12.2013 р./). Простежуємо актуалізування прецедентних виразів. 
Виокремлюємо три типи газетних штампів періоду Революції Гідності. Схарактеризуймо кожен окремо.

1. Ключові й поширені суспільно-політичні вирази, що стосуються подій, пов’язаних з виступами українців проти зміни політичного курсу України або негативної оцінки відповідних явищ чи, навпаки, стосовно ствердження потреби позитивних змін та курсу на Свроінтеграцію. Як слушно зауважують дослідники, суспільно-політичні словосполучення на сьогодні є актуальними у зв'язку зі зростанням ролі та динаміки політичної комунікації [Карабута 2013: 55]. Ключовою для сучасної епохи вважаємо передусім метафоризовану назву, що стала газетним словесним штампом, — це, власне, Революиія Гідноcmi, до якої як синонімні використовують Київський Майдан, Майдан у Києві, Свромайдан та Сврореволючуія. Так окреслюють ті політичні й суспільні зміни в Україні, що виникли як реакція, певний “спротив” проти відходу керівництва держави від схваленого українським народом курсу на Свроінтеграцію, що мало законодавче, правове підгрунтя, та подальшою відмовою від нього. Причиною цих протестів стало надмірне концентрування влади в руках тодішнього Президента України Віктора Януковича та його “сім'і”. Український народ відкрито висловив небажання підпорядковуватися Росії, перетворюватися на одну з їі колоній. Маємо широкий масив контекстів уживання цього виразу, як і інших, що належать до поширених, де маніфестується викладена вище думка, порівн.: “Революція Гідності” (Два роки минуло з початку подій, які назвали Свромайданом, а щуе через деякий час цей термін поступово перетвориться на визначення “Революція Гідності” /,День”, 20.11.2015 р./); “системи Кучми-Януковича" ([...] ми бачимо, як в парламент та взагалі у владу проходять ті, щзо зробили все для того, щ⿻бб не просто укорінилися, а й буйно квітнули пороки “системи Кучми-Януковича" /,День”, 20.11 .2015 р./); протестні виступи (3а 23 роки незалежності Україна пережила чимало народних протестних виступів, зокрема й такі масові, як Помаранчева револючія 2004 року і Револючія гідності 2014-го /,Тиждень. иа”, 05.09.2014р./); стовпи режсму Януковича; антидержавні дії на Сході Украӥни (За Порошенка, Яцеенюка, Турчинова (иість місячів при владі!) жодним чином не були покарані стовпи режсму Януковича, навіть ураховуючи їхню явну підтримку антидержсавних дій на Сході краӥни /,Тиждень. иа”, 05.09 .2014 р./); суб’єкт політичного процесу (Видання пише, щзо Майдан - це історичний момент, коли народ відчуває потребу стати не об' єктом, а суб'єктом політичного процесу в країні /,Радіо свобода”, 21.02.2018 р./).

2. Газетні штампи, у структурі яких використані актуалізовані історичні й застарілі лексичні одиниці. В уяві громадськості діяльність Свромайдану асоціюється з діяльністю Запорізької Січі, зокрема використовуються такі термінологічні словосполучення, як периа сотня, друга сотня, козацький редут (На території Київського Майдану розмішувалися армійські намети з написами 
"Перша сотня”, “Друга сотня” та барикада через Хрещатик, яку називали “Козацьким редутом” /,Fake OFF”, 06.04.2017р./). Актуалізовано й ознаки зовнішнього вигляду справжніх козаків, порівн.: оселедець на голові (Слід зауважити, що елементи козацької організаиії ми можемо також простежити в зовнішньому вигляді маніфестантів (шаровари, оселедці на голові тощо). Під час та після Револючї Гідності стало модно серед молоді мати зачіски на кшталт козащьких/„Fake OFF”, 06.04.2017р./). Як бачимо, в активізованих словосполученнях відтворені терміни, національні та народні символи, що в сучасномуукраїнськомумовленнірозширилисвоюсемантикутапрагматику.

3. Ключове словосполучення українського політичного життя сучасної епохи Революція Гідності, як і Свропейський майдан, та інші синонімні номінації, стало „персоніфікованим, міфологізованим утіленням революції 3 людським обличчям у прямому й переносномузначеннях"[Ставицька 2005: 6]. Революція Гідності символізує, як наголошувалося, відповідні політичні та суспільні зміни в країні. Обидва складники цього словосполучення пишемо 3 великої літери. Прийом капіталізації свідчить про відповідну конотацію, яку має словосполучення - це сукупність таких прагматичних смислів, як 'шана', 'повага', 'гордість', 'патріотизм', 'прагнення до кращих змін'. Як відомо, peволюція - це 1) докорінний переворот у житті суспільства, що приводить до ліквідації існуючого суспільного ладу й утвердження нового, прогресивного;

2) переворот у певній галузі, що приводить до докорінного перетворення, удосконалення чого-небудь [Великий тлумачний словник... 2016: 1185]. Гіdність трактуємо, як (1) сукупність рис, що характеризують позитивні моральні якості, (2) усвідомлення людиною своєї громадської ваги [Великий тлумачний словник... 2016: 219]. Відповідно, словосполучення Революція Гідності внаслідок об'єднання значень його компонентів отримує нове лексичне значення: 'морально-етичний злам у свідомості українців' [Ткачук 2014: 323]. Фіксуємо утворення нового усталеного словосполучення номінативного характеру, яке кваліфікуємо як ключовий термін сучасної епохи, що набуває статусу символу. За своєю структурою воно є двокомпонентним, за типом синтаксичного зв'язку - субстантивно-субстантивним, генітивним, що побудоване за моделлю „іменник + іменник (Р. в.)”.

Отже, на основі аналізу словосполучень, газетних словесних штампів, “народжених” Революцією Гідності, підтверджуємо факт, що розвиток мовице об'єктивний процес, зумовлений поступом суспільства. Першими на зміни в суспільстві реагують засоби масової інформації. Життя сучасної людини тісно пов'язане з політикою, тому взаємозв'язок із суспільно-політичною сферою мовлення залишається актуальним.

Проаналізувавши періодичні видання останніх років, робимо висновок, що газетні словесні штампи виражають систему відтінків емоційно-експресивного забарвлення, репрезентують прагматичну інформацію, є атракцій- 
ними, прецедентними, що надає публікаціям оригінального й привабливого звучання, викликаючи в читача відповідні почуття й думки, налаштовуючи його на сприйняття тих чи тих політичних подій, формулюючи відповідну громадську думку певного аксіологічного скерування. Очевидно, що події к. 2013 - поч. 2014 рр., про які йшлося вище, знайшли втілення в словесних штампах сучасної української мови.

\section{Список використаної літератури}

Великий тлумачний словник сучасної української мови, з дод. і допов., уклад. і гол. ред. В. Т. Бусел, Київ-Ірпінь: ВТФ „Перун”, 2005.

Єфименко О., Диференціація словосполук у мовознавстві на тлі соціальної динаміки, [в:] „Соціум. Документ. Комунікація. Серія: Філологічні науки”, 2017, вип. 3, с. 71-82.

Карабута О., Суспільно-політична лексика у політичному дискурсі: семантичний аспект, [в:] „Науковий вісник ХДУ. Серія: Лінгвістика”, 2013, вип. 19, с. 54-55.

Поліщук Н., Термінологічна лексика Майдану (на матеріалах газет „Дзеркало тижня”, „Украӥнська правда”, „Газета по-украӥнськи”, „Високий Замок”), [в:] „Вісник Національного університету «Львівська політехніка». Серія: Проблеми української термінології”, 2014, № 791, с. 138-143.

Револючія Гідності, [в:] Електронний ресурс: https://uk.wikipedia.org/ (12.07.2018). Славова Л., Мовна особистість у сучасному американському та українському політичному дискурсі, автореф. ... д-ра філол. наук, Київ 2015.

Ставицька Л., Дискурс помаранчевої пристрасті, [в:] „Критика”, 2005, № 3, с. 3-16.

Степаненко М., Українська мова і суспільно-політичні трансформащії сьогодення, [в:]

„Українська мова”, 2015, № 2, с. 3-23.

Стишов О., Тематичні групи термінів-неологізмів у сучасному медіа дискурсі, [в:] „Наукова термінологія нового століття: теоретичні і прикладні виміри”, 2016, с. 102-106.

Таран А., Термінологізація лексики в суспільно-політичному дискурсі, [в:] „Термінологічний вісник”, 2013, вип. 2 (2), с. 138-142.

Ткачук А., „Револючія Гідності”: політологічний аналіз, [в:] „Вісник Львівського університету. Серія: Філософсько-політологічні студії”, 2014, № 5, с. 322-328.

Ясна І., Бекешкіна І., Верстюк В., Єрмоленко А., Жаботинська С., Кебуладзе В., Попович М., Пролеєв С., Сігов О., Трач В., Скуратівський Н., Дискурс Револючиї Гідності: зміст, структура, методологія дослідження (круглий стіл „, Філософської думки”), [в:] „Філософська думка”, 2016, № 4, с. 6-56.

\section{Spysok vykorystanoi literatury [References]}

Velykyi tlumachnyi slovnyk suchasnoi Ukrainskoi movy [Great Explanatory Dictionary of Contemporary Ukrainian Language], z dod. i dopov., uklad. i hol. red. V. T. Busel, KyivIrpin: VTF „Perun”, 2005. 
Yefymenko O., Dyferentsiatsiia slovospoluk $v$ movoznavstvi na tli sotsialnoi dynamiky [Differentiation of Phrases in Linguistics on the Background of Social Dynamics], [v:] „Sotsium. Dokument. Komunikatsiia. Seriia: Filolohichni nauky”, 2017, vyp. 3, s. 7182.

Karabuta O., Suspilno-politychna leksyka u politychnomu dyskursi: semantychnyi aspekt [SocioPolitical Vocabulary in Political Discourse: the Semantic Aspect], [v:] „Naukovyi visnyk KhDU. Seriia: Linhvistyka”, 2013, vyp. 19, s. 54-55.

Polishchuk N., Terminolohichna leksyka Maidanu (na materialakh hazet „Dzerkalo tyzhnia”, „Ukrainska pravda”, „Hazeta po-ukrainsky”, „Vysokyi Zamok”) [Terminological Vocabulary of the Maidan (Based on the Materials of the Dzerkalo Nedeli Newspaper, Ukrayinska Pravda, Ukrayinska Pravda, The Ukrainian Newspaper, the High Castle], [v:]

„Visnyk Natsionalnoho universytetu «Lvivska politekhnika». Seriia: Problemy ukrainskoi terminolohii”, 2014, № 791, s. 138-143.

Revoliutsiia hidnosti [Revolution of Dignity], [v:] Elektronnyi resurs: https://uk.wikipedia.org/ (12.07.2018).

Slavova L., Movna osobystist u suchasnomu amerykanskomu ta ukrainskomu politychnomu dyskursi [A Linguistic Personality in Contemporary American and Ukrainian Political Discourse], avtoref. ... d-ra filol. nauk, Kyiv 2015.

Stavytska L., Dyskurs pomaranchevoi prystrasti [A Discourse of Orange Passion], [v:] „Krytyka”, 2005, № 3, s. 3-16.

Stepanenko M., Ukrainska mova i suspilno-politychni transformatsii sohodennia [Ukrainian Language and Socio-Political Transformations of the Present], [v:] „Ukrainska mova”, 2015, № 2, s. 3-23.

Styshov O., Tematychni hrupy terminiv-neolohizmiv u suchasnomu media dyskursi [Thematic Groups of Terms-Neologisms in Modern Media Discourse], [v:] „Naukova terminolohiia novoho stolittia: teoretychni i prykladni vymiry", 2016, s. 102-106.

Taran A., Terminolohizatsiia leksyky v suspilno-politychnomu dyskursi [Terminologization of Vocabulary in Socio-Political Discourse], [v:] „Terminolohichnyi visnyk”, 2013, vyp. 2(2), s. 138-142.

Tkachuk A., „Revoliutsiia Hidnosti”: politolohichnyi analiz [,,Revolution of Goodwill»: Political Analysis], [v:] „,Visnyk Lvivskoho universytetu. Seriia: Filosofsko-politolohichni studii”, 2014, № 5, s. 322-328.

Yasna I., Bekeshkina I., VerstiukV., Yermolenko A., Zhabotynska S., Kebuladze V., Popovych M., Proleiev S., Sihov O., Trach V., Skurativskyi N., Dyskurs Revoliutsii Hidnosti: zmist, struktura, metodolohiia doslidzhennia (kruhlyi stil ,Filosofskoi dumky”) [Discourse of the Revolution of Dignity: Content, Structure, Methodology of Research], [v:] „Filosofska dumka”, 2016, № 4, s. 6-56. 